\title{
Communication as a Purpose of Existence of Modern Organizations
}

\author{
Aleksandr I. Taranenko* \\ and Galina V. Panasenko \\ Siberian State Technological University \\ 82 Mira Str., Krasnoyarsk, 660049, Russia
}

Received 04.11.2016, received in revised form 12.12.2016, accepted 07.02.2017

In the postindustrial society organizational success depends not only on the direction for profit, but also on the creation of values. One of the priorities in the 21st century is interpersonal communication at a distance. In the trenches of today's business processes are those organizations whose main activity is human communication.

Keywords: communication, management, future, values, adaption, community, Internet, system, management structure.

DOI: 10.17516/1997-1370-0022.

Research area: economics.

At the end of the $19^{\text {th }}$ century, mankind reached an absolutely new level of social interaction. The forms and models of familiar communications began to pull away on the back burner, people spent more and more time on communication in the network, a huge market need for communication at a distance emerged.

Communication as a concept and essence of human interaction has often been the object of study. It is at the end of the $20^{\text {th }}$ century when communication was described not only as a social phenomenon, but as an engine of human progress. The development of communication technology gives the right to say that Alvin Toffler and Tom Stonier were right, claiming that the shift into the post-industrial society would soon happen, which was based on not only the material values but on the exchange, dissemination and creation of information.

According to Isaac Adizesa, the main object of the organization should involve meeting the needs of the market and creating values. The issue is much broader than the business purposes declared, for example, in the Civil Code of the Russian Federation. Of course, the purpose of an organization is to make a profit, but if this organization does not meet the needs of the market, if it does not introduce new ideas, products and services, the revenue is unlikely to be systematic. That is as it should be in the market-business environment.

In the process of globalization and integration at the end of the $20^{\text {th }}$ century some organizations appeared in the Internet. The very

(c) Siberian Federal University. All rights reserved

* Corresponding author E-mail address: sa-taranenko@yandex.ru 
essence of such organizations was to provide goods or services to customers remotely, over the network. Gradually, the world was embraced by a huge crater of communicative relationships. The link was provided by the pioneers of the Internet industry. The mission and purpose of such existing organizations are communications.

The concept of communication in management has been identified relatively recently. According to Michael H. Mescon, communication is the process of exchange of information, its semantic value between two or more people. According to Baxter, as well as Sellars and Vangelisti, communication is the means by which people construct and maintain their relations.

Communication is both one of the reasons and a means of organization formation. The Organization, in its turn, is a group of people whose activities are coordinated deliberately to achieve a common purpose or purposes [4].

For example, according to D.D. Vachugov, organization is a separate union for cooperation towards achieving the goals and objectives. Certainly, the communication is not the first and not the main purpose of the formation. However, in this article we will examine the organization whose primary purpose is to create and support the global interpersonal communication and to get profit as a result.

Communications are an integral part of not only the organization, but also of the contemporary culture. New technological features during already 20 years allow millions of people to communicate without leaving home. This need has identified the necessity to create companies, the main purpose but not just the internal process of which is the formation and development of

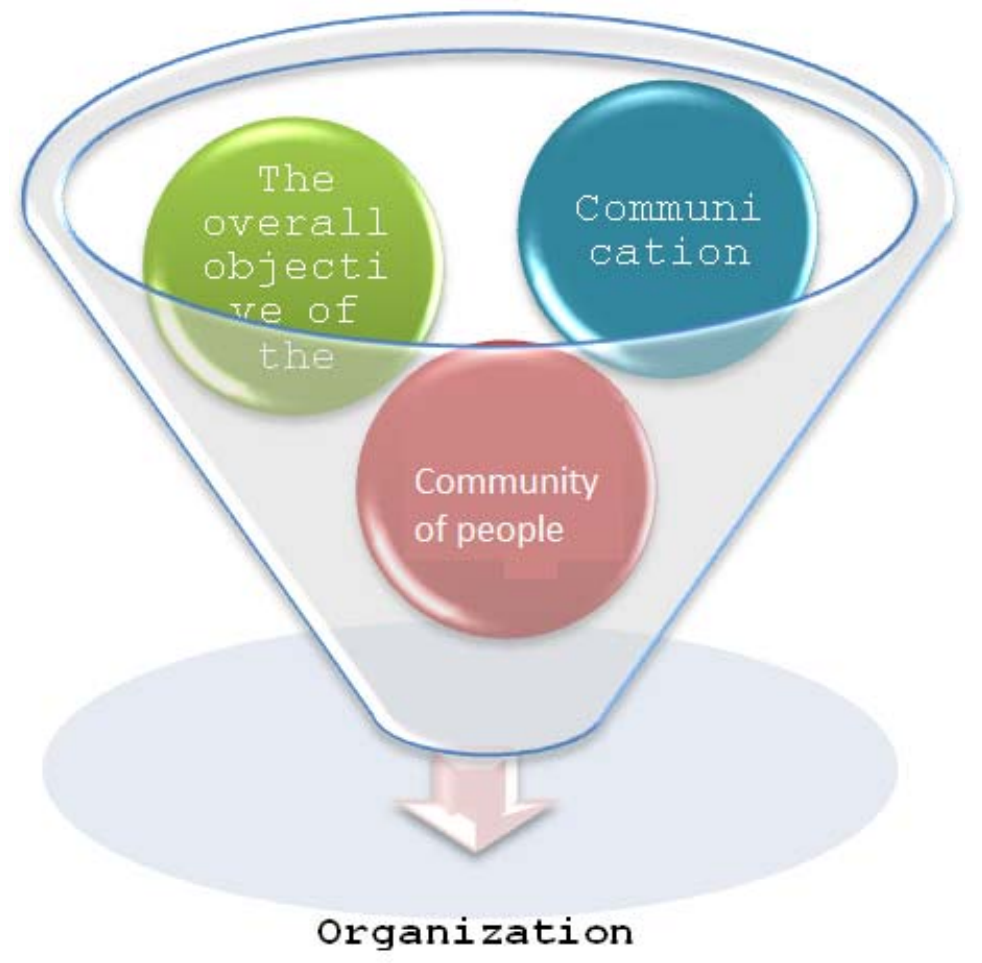

Fig. 1. System of communicative organizations 
universal human communicative possibilities. It can be said that these organizations have created a new communication paradigm. What distinguishes these organizations from all the rest? In order to analyze the internal features of communicative organizations, let us analyze their Missions.

According to O.S. Vikhanskii, the Mission is the expressed approval of what and why the organization exists. Some of the most successful Internet companies that have changed the communicative paradigm are included into the Table 1.

As we can see from the table above, all the companies include communication into their missions. Accordingly, the main purpose of the formation and activities of these organizations is the communicative process in any way.

The development resource of these organizations is not material and it is not limited. The standard economic problems such as the infinity of needs and limited resources are not applied on such kind of organizations. Thanks to the choice of communicative development path, these organizations, as it can be said, have created their own economic model.

The mission of modern communicative organizations is not only functional, but also socially oriented. They do not only get their profit, but also create space for communication in the places where there was no even civilization. These changes are leading to the next milestone in the globalization of the world economy and the globalization of world consciousness. Having examined all of the above mission concepts, it can be concluded that there is the unity of the common goals of communicative organizations. "The creation of instant communication between people without any obstacles" is a reflection of the Mission of all of the above organizations. The mission as a basic purpose draws a clear line between the vision of communication and the vision of the rest of the economic bloc. Vision is the guiding business philosophy, the justification for the existence of the company, it should be borne in mind that this is not the goal itself, but rather the feeling of the main aims of the company, that is the perfect picture of the future, then a condition that can be achieved under the most favourable conditions. The vision identifies the level of claims in the strategic planning process. Vision creates a sense of perspective in the work of the organization, ensures the continuity of the consecutive goals of the firm. Any purpose limits the scope of action of the company, and the vision is not the finish line, it creates momentum for continued progress.

Table 1

\begin{tabular}{|c|l|l|}
\hline № & \multicolumn{1}{|c|}{ Company } & \multicolumn{1}{c|}{ Mission } \\
\hline 1 & Facebook & "To give people the power to share and make the world more open and connected" \\
\hline 2 & Google & "To organize the world’s information and make it universally accessible and useful" \\
\hline 3 & YouTube & "To provide fast and easy video access and the ability to share videos frequently" \\
\hline 4 & Twitter & $\begin{array}{l}\text { "To give everyone the power to create and share ideas and information instantly, without } \\
\text { barriers" }\end{array}$ \\
\hline 5 & Intel & $\begin{array}{l}\text { "Delight our customers, employees, and shareholders by the relentless delivery of the } \\
\text { platform and technology advancements that become essential to the way we work and } \\
\text { live" }\end{array}$ \\
\hline 6 & Yahoo & "To connect people to their passions, communities, and the world knowledge" \\
\hline
\end{tabular}


All the above organizations, features not only a clear vision, built on the mission, but also a number of other important factors.

\section{Take a look at the main features of communicative organizations}

1. The cost is much higher than the actual revenue and the cost of fixed assets.

When one purchases any of the following companies, the payback of investments will be from 15 to 120 years, while the acquisition of large companies with a serious investment payback in 10 years is considered unacceptable (Table 2).

\section{Matrix management structure}

The fundamental governance structure is the «matrix» in most of the above organizations. It is a project of the project organization of labor. There are specialists in dual subordination to the project manager and the head of their functional unit within an organization. Matrix structure offers great opportunities for the effective coordination of the production process. The developed network of horizontal communications in conjunction with hierarchical subordination turns the organization's holistic and fast mechanism for responding to environmental challenges. The matrix structure is an organic combination of two or more specified structures: design and functional regional and commodity, client and regional and so on. The specific feature of matrix structure is the subordination to the two leaders of the same level.

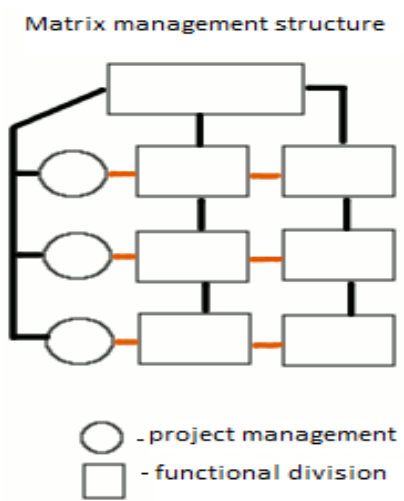

Fig. 2

3. The rapid growth of capital and small investments in «Startups».

All of the listed organizations are growing extraordinarily rapidly; their market capitalization over the years has increased by ten times, making them the richest companies in the world. Almost all of them have taken their starts with minimal investment. Startup is a newly formed organization, which is engaged in the development of new products or services in conditions of an extreme uncertainty [5]. Ideas for successful startups were often found accidentally. For example, the company Lotus began with the fact that Mitch Kapor just wrote a program for his friend. Steve Wozniak, while working for HewlettPackard, wanted to build computers, but the employer did not allow him to implement his ideas. So, this is how Apple appeared. And David Filo, who collected links, never thought that his passion will ever result in a project called «Yahoo!»

Table 1

\begin{tabular}{|l|l|l|l|}
\hline \multicolumn{1}{|c|}{ Company } & \multicolumn{1}{|c|}{ Revenue [3] } & \multicolumn{1}{c|}{ Cost [3] Profit [3] } \\
\hline Facebook & $2.91 *$ & 201.6 & 1.58 \\
\hline Google & 55 & 379.7 & 12.9 \\
\hline Apple & 170 & 600 & 37 \\
\hline
\end{tabular}

* Billions of dollars of the United States 
4. The rapid adaptation to environmental conditions.

Through a flexible management structure, organizations with their goals including human communication adapt to environmental conditions faster than multinational corporations. In addition, these organizations create these conditions in some part. In fact, as a rule, innovative projects in the field of human communication are strongly influenced by the external environment.
It should be noted that it is the human communication in the $21^{\text {st }}$ century that has become the main source of profit for advanced, innovative organizations. Innovative activity, including the field of human resources management in the above mentioned organizations, causes a wide public and managerial interest. The path that the world economy has taken that is a globalization and integration path was paved by the organizations aimed at human communications. They are the engines of the modern economic order.

\title{
References
}

Agamalova, A. Vedomosti [Vedomosti] / A. Agamalova. - Available at: http://www.vedomosti.ru/ tech/news/17686281

Vihanskij, O.S., Naumov, A.I. Menedzhment: Uchebnik [Management: Textbook]. -3 ed./O.S. Vihanskij, A.I. Naumov. - M.: Gardariki, 2006. -528 s.

Gaynulina, A. Lenta.ru / A. Gainulina. Available at: http://lenta.ru/articles/8/20/201 / Date: 12.12.2014.

Meskon, M. H., Albert, M., Hedouri, F. (2012) Osnovy menedzhmenta [Fundamentals of Management] -M., $524 \mathrm{p}$.

Ris, E. (2014) Biznes s nulja. Metod LeanStartup dlja bystrogo testirovanija idej i vybora biznesmodelej [Business from the ground up. The Lean Startup method to quickly test ideas and business model]. Alpina Publisher $-256 \mathrm{p}$.

\section{Коммуникация как цель существования современных организаций}

\author{
А.И. Тараненко, Г.В. Панасенко \\ Сибирский государственный технологический \\ университет \\ Россия, 660049, Красноярск, пр. Мира 82
}

В постиндустриальном обществе успешность организационной деятельности зависит не только от направленности на получение прибыли, но и от создания ценностей. Одной из приоритетных направлений в ХХІ веке является межличностная коммуникация на расстоянии. На передовой современных бизнес-прочессов стоят именно те организачии, основным направлением деятельности которых является человеческая коммуникация.

Ключевые слова: коммуникация, управление, будущее, ценности, культра, общество, Интернет, система, структура управления.

Научная специальность: 08.00.00 - экономические науки. 